\title{
An Interview-Based Approach to Assess Angler Practices and Sea Turtle Captures on Mississippi Fishing Piers
}

\author{
Melissa Cook ${ }^{1 *}$, Victoria S. Dunch ${ }^{1,2+}$ and Andrew T. Coleman ${ }^{3+}$ \\ ${ }^{1}$ Mississippi Laboratories, Southeast Fisheries Science Center, National Marine Fisheries Service, National Oceanic and \\ Atmospheric Administration, Pascagoula, MS, United States, ${ }^{2}$ Smith College, Environmental Science \& Policy Program, \\ Northampton, MA, United States, ${ }^{3}$ Institute for Marine Mammal Studies, Gulfport, MS, United States
}

\section{OPEN ACCESS}

Edited by: Donna Jill Shaver, National Park Service, United States

Reviewed by:

Sara M. Maxwell, University of Washington Bothell,

United States

Susan Gwynn Barco, Virginia Aquarium \& Marine Science

Center, United States

${ }^{*}$ Correspondence: Melissa Cook

melissa.cook@noaa.gov

${ }^{\dagger}$ Present address:

Victoria S. Dunch, Community Engagement, Beckman Center for Conservation Research, San Diego Zoo Global, San Diego,

$C A$, United States

Andrew T. Coleman,

Department of Biology, Talladega College, Talladega, AL, United States

Specialty section:

This article was submitted to

Marine Megafauna,

a section of the journal

Frontiers in Marine Science

Received: 06 January 2020

Accepted: 20 July 2020

Published: 14 August 2020

Citation:

Cook M, Dunch VS and

Coleman AT (2020) An Interview-Based Approach to Assess Angler Practices and Sea Turtle Captures on Mississippi Fishing Piers.

Front. Mar. Sci. 7:655.

doi: 10.3389/fmars.2020.00655
During 2010-2015, the Mississippi Sea Turtle Stranding and Salvage Network (STSSN) documented 1,073 sea turtles, primarily juvenile Kemp's ridleys (Lepidochelys kempii), incidentally caught by recreational anglers. Due to increases in interactions, an angler interview survey was conducted during 2013 at six Mississippi fishing piers. Anglers were interviewed about fishing practices and sea turtle interactions. Interviewers conducted outreach and distributed Rehabilitation Hotline business cards. Angler participation was $86 \%$, and over $60 \%$ used J-hooks and were not targeting specific species, which was similar to data collected from incidental captures reported to the STSSN. Over 58\% of anglers used dead shrimp followed by cut up fish for bait. This greatly differs from STSSN reported captured sea turtles where $60 \%$ were caught on cut up fish and only $6 \%$ on dead shrimp. Over $18 \%$ of participants captured at least one sea turtle in the last 12 months. Anglers stated that nearly half of the sea turtles were taken for rehabilitation, $41 \%$ were released by the angler and $10 \%$ broke the line and swam away. Only 60\% of anglers reported the capture because many were unaware they should report it. During and after the survey period, there was an increase in reported incidental captures, possibly indicating outreach is an effective means of increasing awareness and reporting. Recently, NOAA Fisheries developed a survey that can be used nationally to conduct similar research. We recommend conducting angler surveys every few years unless there is a noticeable change in incidental capture trends or angler practices.

Keywords: sea turtle, incidental capture, fishing pier, angler survey, outreach, recreational angler, bycatch, Kemp's ridley

\section{INTRODUCTION}

Although the Mississippi (MS) coast is small with only $71 \mathrm{~km}$ of general coastline, the highly productive waters of MS Sound draws anglers from all over the state and the rest of the country (National Marine Fisheries Service, 2016). To provide access to fishing and other coastal marine resources, MS has over 200 public access points such as fishing piers, boat launches, and marinas ${ }^{1}$ in its three coastal counties. Access points increased following destruction of most

\footnotetext{
${ }^{1}$ https://gis.dmr.ms.gov/PublicAccess/
} 
fishing infrastructure by Hurricane Katrina in 2005 (AbbottJamieson and Ingles, 2015), and are relevant because recreational anglers in MS more than doubled from 2005 to 2015 (National Marine Fisheries Service, 2016, 2017). Piers and marinas are frequented by anglers whose fishing gear hooks many species of fish, sharks, and also sea turtles (Lyn et al., 2012; Coleman et al., 2016b). From 1998 to 2009 there were a total of ten reported sea turtle incidental captures in MS (Sea Turtle Stranding and Salvage Network $[\mathrm{STSSN}]^{2}$ ). However, beginning in 2010, the number of incidental sea turtle captures reported by recreational anglers began to rise considerably (Lyn et al., 2012; Coleman et al., 2016b). Whether the increased numbers were due to actual increases in numbers of captures, or rather increased awareness to report the captures is unknown. The increase occurred the same year as the Deepwater Horizon oil spill which resulted in hundreds of sea turtle strandings along the MS coast and considerable media attention. These data were collected through the National Oceanic and Atmospheric Administration (NOAA) STSSN, which works to document sea turtle strandings from Maine to Texas (TX). During 20102015, the STSSN documented 1,073 incidentally caught sea turtles along the MS coast (Figure 1), primarily caught from 29 different access points.

The majority of incidental captures in MS from 2010 to 2015 were juvenile Kemp's ridleys (89\%) (Lepidochelys kempii) $\left(\mathrm{STSSN}^{2}\right)$, which are the smallest and most endangered of all sea turtle species (Marquez, 1994; Caillouet et al., 2018; Wibbels and Bevan, 2019). Neritic zones in the Gulf of Mexico and western North Atlantic Ocean represent important foraging habitats for

$\overline{{ }^{2} \text { https://grunt.sefsc.noaa.gov/stssnrep/ }}$
Kemp's ridleys (National Marine Fisheries Service, U. S. Fish and Wildlife Service, and SEMARNAT, 2011). Satellite telemetry has shown the northern Gulf of Mexico as a primary foraging ground for Kemp's ridleys (Shaver et al., 2013, 2016), and, specifically, the MS Sound represents an important recruitment and developmental habitat (Coleman et al., 2016a). This species was on the brink of extinction in the 1970s and 1980s, but it experienced a population recovery due to intense management and conservation efforts (National Marine Fisheries Service, U. S. Fish and Wildlife Service, and SEMARNAT, 2011). The higher number of turtles, combined with an increased number of anglers using recently constructed piers in coastal MS, may have resulted in the increases in incidental captures. Due to the high number of interactions, a pilot survey was developed in 2013 by NOAA's National Marine Fisheries Service (NOAA Fisheries), NOAA's MS Laboratories (MS Labs), and the Institute for Marine Mammal Studies (IMMS) to collect data on angler fishing practices and sea turtle interactions. Each survey concluded with outreach efforts aimed to educate anglers and curtail incidental captures. The ultimate goal was to determine if mitigation measures could be developed to minimize the number of recreational hook and line captures on MS fishing piers.

\section{MATERIALS AND METHODS}

To address the sudden rise of incidental sea turtle captures in MS, NOAA, and IMMS created a pilot survey with several objectives. The first was to gather data on angler practices and experiences on MS coastal access points, and the second was to determine frequency of both sea turtle incidental captures and reporting of captures to local agencies. The survey also served as

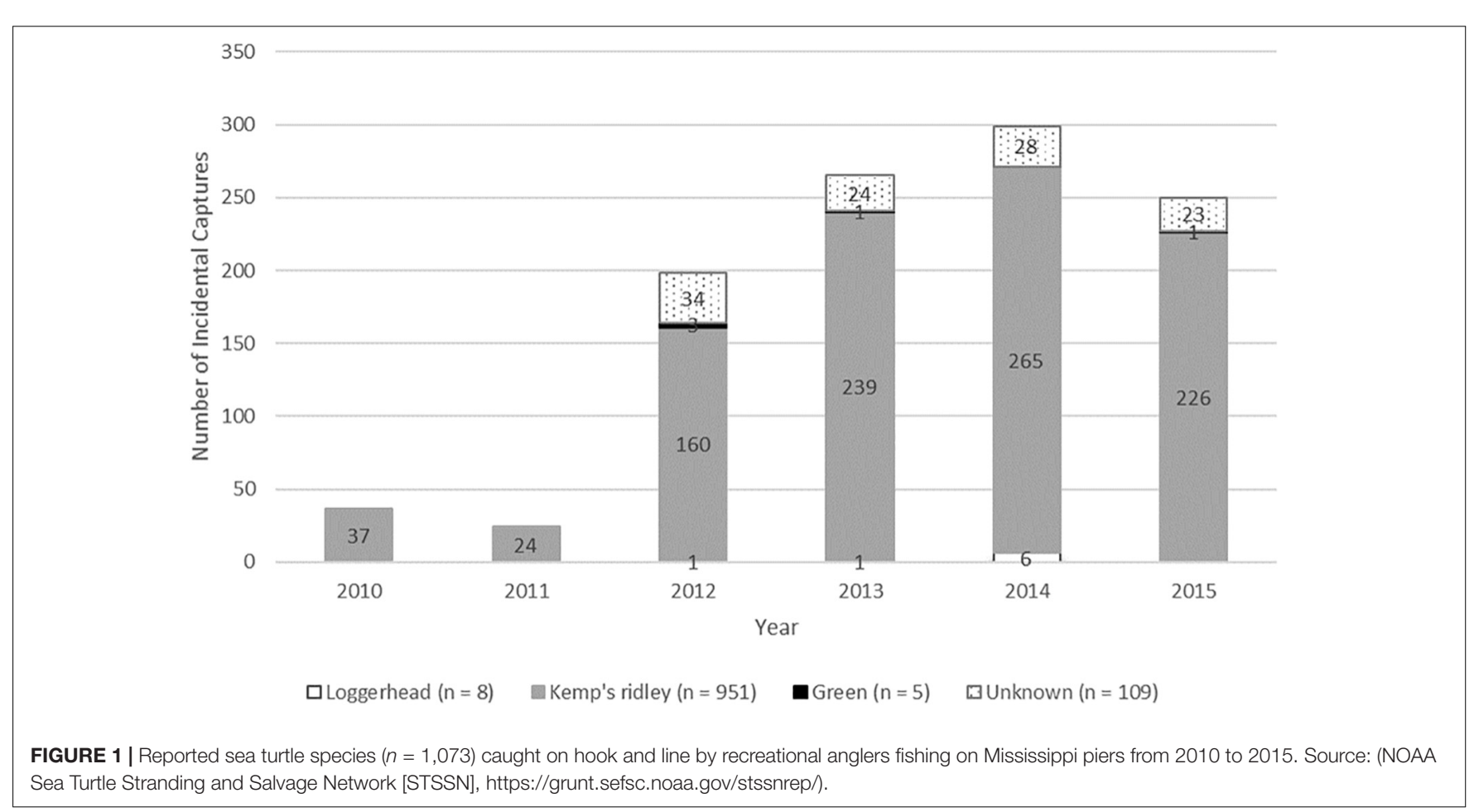


an educational outreach tool to inform anglers about procedures they should take if they hooked a sea turtle.

\section{Study Sites}

Six fishing sites (Figure 2) were selected along MS's three coastal counties. Sites were selected based on several factors including availability (many fishing piers and marinas in western MS were destroyed in 2012 storms), location, type of fishing access point, and number of previously reported incidental captures. If possible, the site with the highest number of incidental captures in each county was selected and also sites with zero or low reports to allow for comparison. Reported incidental captures at the sites ranged from zero to 56 reports (prior to the start of the survey). Sites included four fishing piers, a fishing bridge and a former marina. Jackson County piers included Pascagoula Beach Park Pier (PB; 30 $20.595 \mathrm{~N},-88^{\circ} 32.019 \mathrm{~W} ; 305 \mathrm{~m}$ long), Chester M. McPhearson, Jr. Pier (CM; 30 $24.31 \mathrm{~N},-88^{\circ} 49.768 \mathrm{~W}, 165$ $\mathrm{m}$ long) and the Ocean Springs Fishing Pier (OS; $30^{\circ} 24.681 \mathrm{~N}$, $-88^{\circ} 50.484 \mathrm{~W} ; 402 \mathrm{~m}$ long) which opened in February 2012. Harrison County contained the two largest sites in the study. The newly constructed Old Biloxi Fishing Bridge (OBB) $\left(30^{\circ}\right.$ $\left.23.792 \mathrm{~N},-88^{\circ} 51.552 \mathrm{~W}\right)$ opened on April 30, 2013 and had reported incidental captures within 2 weeks. The OBB is $1,433 \mathrm{~m}$ long, has two lanes of traffic, sidewalks and lighting. The second site in Harrison County was the old Broadwater Marina (BW; $\left.30^{\circ} 23.503 \mathrm{~N},-88^{\circ} 57.760 \mathrm{~W}\right)$ site. The Broadwater Marina was destroyed in 2005 during Hurricane Katrina but the land is still accessible to anglers by vehicle and offers over $2,100 \mathrm{~m}$ of water access. Hancock County had the highest number of reported incidental captures at the survey start time. However, the Washington Street Fishing Pier (WS; $30^{\circ} 18.137 \mathrm{~N},-89^{\circ}$ $19.642 \mathrm{~W}$ ) was the only site selected because the other piers in Hancock County were still closed due to damage from Hurricane Isaac in 2012. The WS was also damaged in Hurricane Isaac and was closed from August 2012 through early June 2013. The WS has a $110 \mathrm{~m}$ fishing pier but also has an expansive parking area with fishing access and two jetties which add an additional $450 \mathrm{~m}$ of fishing access. In February 2012, informational signs about sea turtle incidental capture, handling, and reporting were placed on any MS fishing piers not already equipped with signs.

\section{Angler Survey}

The MS Fishing Pier Angler Survey Cover Sheet (Supplementary Table 1) and Angler Survey (Supplementary Table 2) were designed based on similar surveys conducted by the Chicago Zoological Society/Sarasota Dolphin Research Program and the NOAA Fisheries Southeast Regional Office. The survey was designed using established methods (Robson and Jones, 1989) and incorporated a variety of questions to assess MS angler fishing practices and sea turtle interactions. All documents

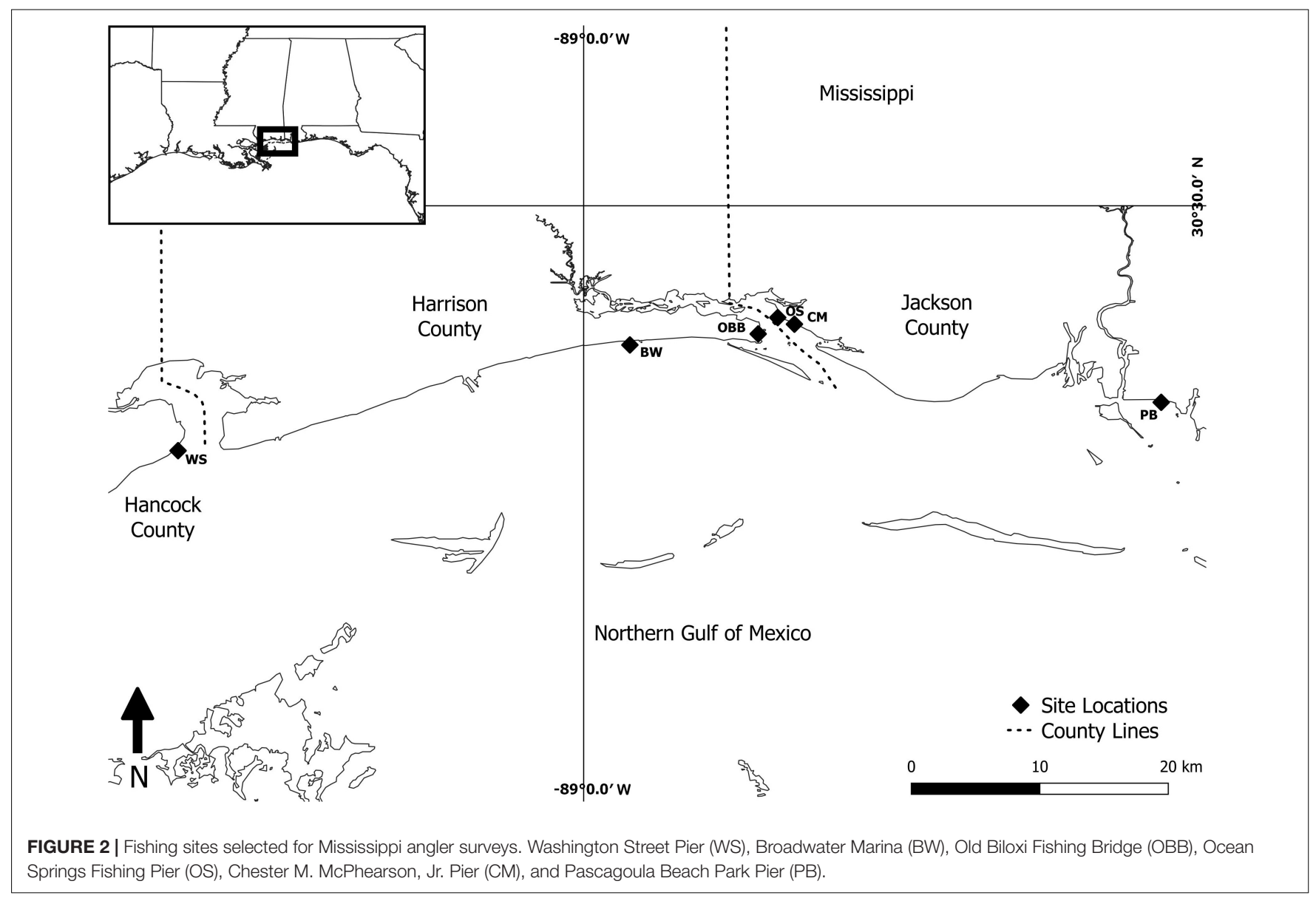


have undergone independent review pursuant to the Paperwork Reduction Act (PRA) of 1995 (44 U.S.C. 3501 et. seq.), OMB Control Number 0648-0774, and are compliant with The Privacy Act of 1974 (5 U.S.C. 552a). Collection of these data on sea turtle interactions in the pier-based recreational fishing sector is necessary to fulfill statutory requirements of the Endangered Species Act (16 U.S.C. 1531 et. seq.). All recorded data were entered and archived in a Microsoft ${ }^{\mathrm{TM}}$ Access database.

\section{Angler Interviews}

Preceding the start of the survey, interviewers read a statement identifying that they were working with NOAA Fisheries and the IMMS to conduct a research study on angler fishing practices, the information collected would be combined with responses provided by other recreational anglers and used only for scientific research, statistical and publication purposes. Anglers were advised the survey would take about $5 \mathrm{~min}$, participation was completely voluntary and all answers were confidential. No minors were interviewed for this study and no personally identifiable information was recorded. Lead researcher contact information was available upon request if participants had questions about the research or respondent rights.

Prior to conducting the interviews, eight staff and interns were trained to deliver the survey in a consistent manner to ensure standardized measurement (Fowler, 2014). Interviewers received training on survey objectives, and sea turtle outreach information, and were supervised during initial surveys to ensure consistency. All interviewers were also trained on how to safely handle an incidentally caught sea turtle, in the event that one was hooked while interviewers were present at fishing locations. Interviewers were equipped with survey materials, Rehabilitation Hotline business cards, and large plastic bins to safely transport a sea turtle, if necessary.

Interviews were conducted one-on-one by staff and interns from MS Labs and IMMS. These were done opportunistically (due to staff availability) from late June through September 2013, and occurred on weekends and week days. Starting time (morning, midday, and evening) and survey site varied to achieve a representative sample (Fowler, 2014). Interviewers documented wave height and tidal conditions, number of anglers and lines in the water and number of anglers declining to participate. The goal was to interview all anglers present at the site, if possible. If time or weather prevented completion of angler interviews, counts of anglers and lines fished were conducted for missed anglers. Anglers were asked questions such as state residency, where and when they preferred to fish, target catch, bait and hook type, fish cleaning and bait disposal practices. The final set of questions was specific to sea turtles observed or incidentally captured within the last 12 months in MS. If the angler had incidentally captured a sea turtle they were asked where and when the most recent capture occurred, interaction type (hooked or entangled), outcome of the capture (line broke, turtle released, turtle taken to rehabilitation facility) and if the angler reported the capture to the stranding network or state agency.

Interviews concluded with angler outreach where anglers were told about sea turtles found in MS waters, fishing practices that can reduce interactions (i.e., do not cast in the direction of a sea turtle or discard unused bait in the water), and what to do if they accidentally caught a sea turtle. This included advice to immediately call the rehabilitation center hotline, do not pull a sea turtle up by the line but instead use a net or walk it down to the beginning of the pier, and do not cut the fishing line and release the animal. Business cards with the rehabilitation center hotline number were distributed and advised to be placed in anglers tackle boxes, wallets, or glove boxes since vehicles were often in close proximity to anglers. Typical interviews and outreach lasted 5 to $10 \mathrm{~min}$ but frequently took longer as anglers were interested in learning about sea turtles and sharing stories of incidental captures.

\section{Sea Turtle Incidental Capture Data Collection}

Beginning in 2012, the MS STSSN introduced the Sea Turtle Incidental Capture Intake Form (STICIF) to collect information on fishing gear and interaction type. This was collected in addition to the standard STSSN data (e.g., date, location, species, size, etc.). When an angler reported an incidental capture they were asked about fishing practices such as target species, hook type, and bait type used at time of capture. Details on interaction type (i.e., hooked, entangled), gear location (i.e., tongue, esophagus, beak) and outcome (i.e., released by angler, rehabilitated and released, died) were recorded by the veterinarians and staff at IMMS upon admission into rehabilitation. STICIF data from 2012 to 2015 were then compared to angler survey results.

\section{RESULTS}

\section{Study Sites}

The six selected piers comprised $45 \%$ of reported incidental captures prior to the start of the survey, and 53\% of reported captures post survey. From 2010 to 2015, the WS pier followed by BW site had the highest numbers of reported captures, 254 and 160 , respectively $\left(\mathrm{STSSN}^{2}\right)$. Anglers interviewed also reported catching the majority of sea turtles at these two sites but reported more captures at the BW site than the WS pier. The PB site, which had zero reported incidental captures prior to the survey, had 19 reported captures post survey through 2015. The other sites (CM, OS) with low reports pre survey (9 total) continued to have low numbers post survey, 12 additional reports. Site size did not have any apparent influence on the numbers of incidental captures.

\section{Angler Demographics}

Surveys were conducted on 28 days at 81 site visits over the 3 -month period. Angler and line counts were completed at $91 \%$ of site visits. Interviewers observed 1,042 anglers fishing using 1,283 fishing poles. The majority of anglers were observed at the two largest fishing sites, OBB $(44 \%, n=459)$ and BW $(24 \%, n=246)$. Over half $(63 \%)$ of the site visits were conducted Monday through Thursday. Although only $37 \%(n=30)$ of site visits were Friday through Sunday, $42 \%$ of surveys $(n=160)$ were completed during weekends. Over $54 \%$ of anglers $(n=565)$ were fishing during a 
falling tide followed by nearly equal numbers fishing during high $(20 \%, n=211)$ and rising $(18 \%, n=186)$ tides, and only $8 \%$ of anglers $(n=82)$ were fishing during low tide.

Anglers had a high willingness to participate, resulting in 382 completed surveys from 534 anglers approached. During the survey period, $15 \%(n=79)$ of anglers approached had already participated in the survey and were not interviewed a second time. Only $12 \%$ of approached anglers $(n=63)$ declined to answer survey questions and $2 \%(n=10)$ of anglers did not participate due to language barriers. Therefore, only $14 \%$ of approached anglers were unwilling to participate resulting in $86 \%$ of anglers participating. The majority of anglers surveyed (89\%, 336 out of 377 responses) were from MS, $83 \%$ were from the three coastal counties. Anglers from Louisiana (LA), Alabama (AL), and Florida (FL) comprised 5\% of anglers surveyed. Almost half of the anglers interviewed reported they fished year round. Although seasonal fishing also occurred, 36\% fished primarily in summer, $13 \%$ in spring, $5 \%$ in fall, and only $1 \%$ in winter. Few respondents were "new to fishing" (15\%) or "occasional" (1-15 times per year) anglers (8\%). The majority were experienced anglers who fished $16-50$ days $(25 \%)$ or more than 50 days per year (52\%). Time of day anglers reported fishing varied for most (43\%) although $\sim 38 \%$ of anglers preferred to fish in the morning. A preference for all day fishing was reported $19 \%$ of the time and $\sim 11 \%$ of respondents reported fishing in evening or night hours.

Unused bait was discarded into the water by $44 \%(n=163$ of 374 responses) of anglers surveyed and sometimes discarded $12 \%(n=44)$ of the time. The remaining $45 \%(n=167)$ of anglers either said they fished until all of the bait was gone or kept it for another day. While bait was discarded into the water nearly half of the time, that was not the same for fish discards. Most anglers surveyed ( $86 \%, n=318$ of 371 responses) did not clean fish at the fishing piers or discard carcasses into the water. Although, the few anglers who cleaned carcasses on the pier discarded those remains $85 \%$ of the time.

\section{Angler Survey and STSSN/STICIF Comparisons}

Most anglers surveyed $(65 \%, n=247)$ were not targeting a specific fish species. Those that were targeted were drum $(14 \%, n=53)$, primarily red drum (Sciaenops ocellatus) or black drum (Pogonias cromis), and trout (Sciaenidae) $(11 \%, n=41)$, speckled trout (Cynoscion nebulosus) or sand seatrout (C. arenarius). Even fewer anglers targeted sharks (Carcharhinidae), flounder (Paralichthys sp.) or other species ( $\leq 4 \%$ each). Over $63 \%$ of anglers $(n=239)$ reported using J-hooks and 22\% $(n=84)$ reported using circle hooks. Considerably fewer anglers used kahle hooks, jigs and other hook types (Table 1). Those results were very similar to STICIF data collected at the time of incidental capture during 2012-2015. Those data found J-hooks comprised over half of documented captures, followed by circle hooks, kahle hooks and other types of gear (Table 1). Overall, an average of $58 \%$ of anglers interviewed were using dead shrimp (Penaeus sp., range: $28-73 \%)$ followed by cut up fish (21\%, range: 3-69\%) for bait and $10 \%$ (range: $0-13 \%$ ) of anglers used live shrimp (Table 2). Results for individual piers varied considerably, 69\% of anglers
TABLE 1 | Hook type used by recreational anglers during the 2013 Angler Survey and 2012-2015 sea turtle incidental captures.

\begin{tabular}{lccc}
\hline Hook type & $\begin{array}{c}\text { 2013 Angler } \\
\text { survey } \\
(\boldsymbol{n}=\mathbf{3 7 8})\end{array}$ & $\begin{array}{c}\mathbf{2 0 1 3} \text { STICIF } \\
(\boldsymbol{n}=\mathbf{2 6 2})\end{array}$ & $\begin{array}{c}\mathbf{2 0 1 2 - 2 0 1 5} \\
\text { STICIF } \\
(\boldsymbol{n}=\mathbf{1 , 0 0 8 )}\end{array}$ \\
\hline Circle & $22 \%$ & $17 \%$ & $16 \%$ \\
J-hook & $63 \%$ & $52 \%$ & $54 \%$ \\
Jig & $3 \%$ & $0 \%$ & $0 \%$ \\
Kahle & $6 \%$ & $7 \%$ & $4 \%$ \\
Other & $4 \%$ & $1 \%$ & $1 \%$ \\
Treble & $1 \%$ & $0 \%$ & $1 \%$ \\
Unknown & $0 \%$ & $23 \%$ & $24 \%$
\end{tabular}

Incidental capture data from Sea Turtle Incidental Capture Intake Form (STICIF) used by the MS Sea Turtle Stranding and Salvage Network.

TABLE 2 | Bait type used by recreational anglers during the 2013 Angler Survey and 2012-2015 sea turtle incidental captures.

\begin{tabular}{|c|c|c|c|}
\hline Bait type & $\begin{array}{c}2013 \text { Angler } \\
\text { survey } \\
(n=378)\end{array}$ & $\begin{array}{c}2013 \text { STICIF } \\
(n=262)\end{array}$ & $\begin{array}{c}2012-2015 \\
\text { STICIF } \\
(n=1,008)\end{array}$ \\
\hline Crab & $1 \%$ & $2 \%$ & $2 \%$ \\
\hline Cut fish & $21 \%$ & $69 \%$ & $63 \%$ \\
\hline Dead shrimp & $58 \%$ & $8 \%$ & $8 \%$ \\
\hline Live fish & $2 \%$ & $2 \%$ & $1 \%$ \\
\hline Live shrimp & $10 \%$ & $1 \%$ & $0 \%$ \\
\hline Other & $8 \%$ & $5 \%$ & $4 \%$ \\
\hline Unknown & $0 \%$ & $13 \%$ & $21 \%$ \\
\hline
\end{tabular}

Incidental capture data from Sea Turtle Incidental Capture Intake Form (STICIF) used by the MS Sea Turtle Stranding and Salvage Network.

on the WS pier and $48 \%$ of anglers on PB pier used cut up fish as their primary bait. Mullet (Mugil cephalus) and Atlantic croaker (Micropogonias undulatus) were the most common fish used as cut bait. Dead shrimp was the primary bait used at the remaining sites. According to the STICIFs, over $60 \%$ of sea turtles were caught by anglers using cut up fish and only $8 \%$ on dead shrimp (Table 2). Mullet and Atlantic croaker were still the top species consumed by sea turtles at fishing piers, according to STICIF data. Bait data were not available for $23 \%$ of sea turtle captures.

Sea turtles were observed swimming near fishing piers by $37 \%$ of anglers surveyed $(n=139)$, and $28 \%$ of anglers $(n=104)$ we spoke to reported they saw someone catch a sea turtle within the last 12 months. During the last year, $18 \%$ of anglers $(n=66)$ had personally caught one sea turtle and some reported capturing multiple sea turtles. Anglers reported the majority of sea turtle captures (75\%) occurred between June and August. Results are similar to STSSN data $(n=1,073)$ where $80 \%$ of captures occurred in May through August with an additional 10\% of captures reported in September. According to the MS STSSN ${ }^{2}$, all sea turtles captured and measured $(n=876)$ were juveniles or subadults [range 19.5-72.5 cm straight carapace length (SCL)]. The mean SCL for Kemp's ridleys, loggerheads (Caretta caretta) and greens (Chelonia mydas) was 31,36, and $33 \mathrm{~cm}$, respectively.

The anglers interviewed reported that most sea turtles were hooked $(94 \%)$ by the fishing gear and 3\% were entangled in 
the line. Some sea turtles (3\%) were both hooked and entangled in the line. Data regarding specific hook location were not collected. STICIFs documented similar trends. Not all anglers were available for interview when responders arrived to pick up the incidentally caught sea turtle. As a result, approximately $12 \%$ of interaction types were unknown. Of those captures where STICIF data are available $(n=1,012)$, the majority $(84 \%)$ of sea turtles were hooked, $2 \%$ were entangled and only $1 \%$ were both hooked and entangled. Most sea turtles $(92 \%, n=737)$ were hooked while actively targeting the bait and only $8 \%(n=63)$ were externally foul hooked. The esophagus was the most common (57\%) internal hook location followed by unspecified mouth areas (17\%). Most sea turtles were foul hooked in the flipper ( $n=52,83 \%)$. Interviewed anglers in our study stated that hooked sea turtles broke the line and swam away in $11 \%$ of the incidents. Many anglers (41\%) released the sea turtles at the fishing pier while others (48\%) called the stranding hotline so the sea turtle could be taken to IMMS for rehabilitation. Surveyed anglers said they reported the incidental capture $60 \%$ of the time, therefore, nearly half of incidental captures beginning summer 2012 to summer 2013 were undocumented. During angler outreach, interviewers learned that many anglers were unaware that sea turtles were in MS waters or that they should report incidental captures.

\section{DISCUSSION}

The interactions between sea turtles and commercial fishing has been studied extensively (Henwood and Stuntz, 1987; Poiner and Harris, 1996; Sasso and Epperly, 2006) but limited information is publicly available for sea turtle interactions with recreational hook and line fisheries. The TX STSSN has documented recreational captures since the early 1980s (Cannon et al., 1994), and Rudloe and Rudloe (2005) reported on Kemp's ridleys incidentally captured by Florida (FL) anglers from 1991 to 2003. Incidental captures have occurred along both the Gulf of Mexico and western North Atlantic coasts $\left(\mathrm{STSSN}^{2}\right)$. Observations in MS were similar to those in Virginia (VA) where incidental captures increased from 2013 to 2017 and Kemp's ridleys were the dominant species captured (Rose et al., 2018). It is likely that incidental captures are also unreported because anglers are either unaware, unable or unwilling to report the incident. The Federal Kemp's Ridley Recovery Plan identifies the reduction of hook and line interactions as a high priority action (National Marine Fisheries Service, U. S. Fish and Wildlife Service, and SEMARNAT, 2011). A nearly eightfold increase in reported incidental captures in Mississippi in 2012 (Figure 1) prompted the development of the STICIF to gather data on hook and line captures. However, data on angler practices must also be obtained in order to determine if mitigation measures could be developed to minimize the number of recreational hook and line captures.

Data from the MS STSSN and STICIF indicated incidental captures in MS were similar to those in VA, TX, and FL. Juvenile Kemp's ridleys (20-40 cm SCL size range) were the dominant species captured in all locations (Cannon et al.,
1994; Rudloe and Rudloe, 2005; Seney and Musick, 2005; Rose et al., 2018). Although crustaceans, mainly crabs, are known as the primary diet for Kemp's ridleys, fish bait was heavily consumed in all locations (Cannon et al., 1994; Rudloe and Rudloe, 2005; Rose et al., 2018). Diet studies and necropsies of stranded Kemp's ridleys also indicate that fish, likely bycatch discards, are a common prey item (Stacy, 2015; Ramirez et al., 2020). However, regional differences did exist because angler practices often vary by location and target species. In VA, squid was the primary bait type for anglers and the majority of hooked turtles (Rose et al., 2018). In MS, squid was rarely used as bait on fishing piers. In both MS and VA, J-hooks were the most commonly observed hook type followed by circle hooks (Rose et al., 2018). Based on our survey results, the most promising mitigation measure to reduce sea turtle incidental captures is to limit or eliminate the use of fish as bait. There was a notable difference between the bait type used by anglers interviewed (dead shrimp) and the bait type used by anglers that incidentally caught sea turtles (dead fish). This idea is supported when individual fishing sites were examined. Anglers interviewed at WS, were primarily using fish as bait, which may explain the high number of incidental captures at this location. Anglers at BW, second highest reported captures, reported using dead shrimp (44\%) and fish (31\%). During 2012-2015, 635 sea turtles were captured by anglers using dead fish as bait versus only 81 sea turtles caught on dead shrimp. However, this would likely not be favored by the fishing community and prove very difficult to enforce. It would also not reduce foul hooking interactions. Anglers could be encouraged to use non-stainless steel or barbless hooks, especially during spring and summer when turtles are present (Coleman et al., 2016a), and according to our findings, anglers are most likely to be fishing. Areas with fishing piers should promote the safe handling of captured sea turtles and reporting of captures so animals can receive proper medical attention. The IMMS has successfully rehabilitated and released $96 \%$ of incidentally captured sea turtles (Coleman et al., 2016b). Many of these sea turtles had multiple ingested hooks indicating that they were previously captured (Heaton et al., 2016). Depending on the hook location, medical intervention, if available, is necessary to decrease the likelihood of a mortality.

The STSSN has no way of knowing how many incidental sea turtle captures go unreported annually, however, since 2013 the number of sea turtles released by anglers on site has decreased over time. According to the STSSN, in 2012, $18 \%$ of incidentally caught sea turtles were released by anglers or broke the line and swam away. Our 2013 Angler Survey included outreach and education at the end of every interview to ensure that anglers were aware of what to do if they caught a sea turtle and who to call to report the incident. During discussions with anglers, interviewers learned that many of the anglers did not know they should report all sea turtle incidental captures. The number of reported sea turtle incidental captures increased throughout the survey period and continued into the fall; according to the STSSN, 2013 had the highest number of reported captures to date $(n=265)$. Post survey, 
reports occurred from every site, including $\mathrm{PB}$, which had zero reports prior to our survey. Three times more incidental captures were reported to the STSSN in August through October 2013 than in the three previous years. The following 2 years also had high reported incidental captures of 250 or more. Anglers began reporting sea turtle incidental captures when the line broke and the sea turtle swam away. Outreach efforts likely helped contribute to this increase in reported captures and sea turtles receiving treatment and rehabilitation for any injuries.

The 2013 pilot survey was one of the first attempts nationally to obtain information from anglers regarding fishing practices and sea turtle interactions on fishing piers. Since sea turtles are a protected species we were not sure if anglers would be willing to discuss past interactions. This created the potential for social desirability bias among respondents, especially in regards to sensitive questions such as asking respondents if they reported incidental sea turtle captures (Connelly et al., 2012). Techniques such as randomized response or having participants self-administer sections of the questionnaire (Nederhof, 1985) could address biases in future studies. We had an $86 \%$ response rate; on average only one angler (range 0-9) refused to participate at each site. Therefore, anglers were willing to participate and the majority of anglers answered all questions. Only questions regarding discarding unused bait and location of fish cleaning were not answered by all anglers. Many federally funded surveys strive for response rates of 75-80\% (Draugalis et al., 2008; Hendra and Hill, 2019) and those targets were exceeded in this survey. Staff and intern availability limited the survey to summer months and opportunistic rather than standardized sampling design. Although the timing was ideal to match up with when anglers are most likely fishing (according to our findings), and sea turtles are present in MS waters (Coleman et al., 2016a). Interviewers even encountered $15 \%$ of anglers that had already participated in this study. In the future it would be useful to conduct Angler Surveys in the spring, fall, and winter months to both compare against and confirm these preliminary findings.

The incidental capture of juvenile sea turtles by hook and line, and the impacts of those captures are not documented as consistently as sea turtle strandings. It is recommended that stranding networks conduct outreach and education in areas where sea turtles are likely to interact with recreational anglers. Implementation of the STICIF by all STSSN partners would greatly increase our knowledge of factors associated with sea turtles feeding on fishing piers. Since 2013, the original survey has been amended and improved. The success of this pilot survey resulted in NOAA Fisheries developing a survey and instruction manual ${ }^{3}$ that can be used by other states and organizations to conduct similar research in their respective areas. Since recreational interactions have increased, funding is becoming available to study this issue. The Region-wide Trustee Implementation Group (TIG) noted projects that "Reduce sea turtle bycatch in pier- and shore-based recreational fisheries

\footnotetext{
${ }^{3}$ https://www.fisheries.noaa.gov/national/marine-life-distress/sea-turtles-andrecreational-fishing
}

by evaluating, developing, and implementing conservation measures (Approach 4: Technique 1)" were considered a priority area for Region-wide TIG restoration consideration ${ }^{4}$. By expanding the survey regionally or nationally, data can be compared to determine if trends exist throughout the Gulf of Mexico and Atlantic states. Other stranding networks are now using the STICIF and results could be compared to angler surveys. The combination of these two data sets could allow managers to determine types of mitigation measures that could be implemented to reduce the number of sea turtle incidental captures on fishing piers.

Angler surveys likely only need to be conducted every few years unless there is a noticeable change in incidental capture trends. The number of reported incidental captures in MS in $2014(n=299)$ and $2015(n=250)$ were consistent to the previous years $(2012-2015$ mean $=255)$ before drastically falling from 2016 to 2019 (averaging 24 captures annually). It is unknown whether this decrease was due to lower populations of immature Kemp's ridleys in the MS Sound, decreased numbers of sea turtles feeding at fishing piers, a need for regular angler outreach or a recent hesitance of recreational anglers to report captures. During 2012-2019, documented sea turtle strandings in MS also varied greatly from as low as 68 in 2015 or as high as 213 in 2013 with an annual mean of 142. Interestingly enough, a large-scale mortality event occurred in Kemp's ridleys in 2010, and the population trajectory has not recovered from pre-2010 estimates (Gallaway et al., 2016; Caillouet et al., 2018). Instead, annual nesting numbers have shown fluctuations since 2010, and these fluctuations may indicate that this species has reached carrying capacity within the Gulf of Mexico, potentially because of decreased prey population levels (Gallaway et al., 2016; Caillouet et al., 2018). These decreased prey population levels (particularly blue crabs) could have partially provided impetus for immature Kemp's ridleys to forage around recreational fishing piers. Nevertheless, the recent decline in reported incidental captures could be a reflection of decreased nesting numbers, given the 2-4 years of lag time for immature individuals to recruit to neritic habitats. This may be the case in 2017, which had both low stranding and incidental capture numbers. During 2016-2019, the annual stranding average was 132 animals, suggesting that sea turtles are still present in the MS Sound. If incidental capture numbers continue to be low throughout MS, researchers should determine if recreational anglers are still willing to report incidental captures by initiating another Angler Survey and outreach.

\section{DATA AVAILABILITY STATEMENT}

The datasets generated for this study are available on request to the corresponding author.

\footnotetext{
${ }^{4}$ https://www.gulfspillrestoration.noaa.gov/2019/09/submit-your-ideas-regionwide-trustee-implementation-group-restoration-planning
} 


\section{ETHICS STATEMENT}

The studies involving human participants were reviewed and approved by the United States Office of Management and Budget via the Paperwork Reduction Act (PRA) of 1995 (44 U.S.C. 3501 et. seq.), OMB Control Number 0648-0774. Written informed consent for participation was not required for this study in accordance with the national legislation and the institutional requirements.

\section{AUTHOR CONTRIBUTIONS}

MC and AC contributed conception and design of the study. VD conducted the fieldwork. MC wrote the first draft of the manuscript. VD and AC wrote sections of the manuscript. All authors contributed to manuscript revision, read and approved the submitted version.

\section{REFERENCES}

Abbott-Jamieson, S., and Ingles, P. (2015). Natural and manmade disasters: continuing nemesis for Louisiana, Mississippi, and Alabama fishing communities pre- and post-Katrina. Mar. Fish. Rev. 77, 1-16. doi: 10.7755/MFR.77.3.1

Caillouet, C. W. Jr., Raborn, S. W., Shaver, D. J., Putman, N. F., Gallaway, B. J., et al. (2018). Did declining carrying capacity for the Kemp's ridley sea turtle population within the Gulf of Mexico contribute to the nesting setback in 2010-2017? Chelonian Conserv. Biol. 17, 123-133. doi: 10.2744/ccb1283.1

Cannon, A. C., Fontaine, C. T., Williams, T. D., Revera, D. B., and Caillouet, C. W. Jr. (1994). "Incidental catch of Kemp's Ridley Sea Turtles (Lepidochelys kempi), by hook and line, along the Texas coast, 1980-1992," in Proceedings of the Thirteenth Annual Symposium on Sea Turtle Biology and Conservation, eds B. A. Schroeder, and B. E. Witherington (NOAA Tech. Memo. NMFS-SEFSC-341), $40-42$.

Coleman, A. T., Pitchford, J. L., Bailey, H., and Solangi, M. (2016a). Seasonal movements of immature Kemp's ridley sea turtles (Lepidochelys kempii) in the northern Gulf of Mexico. Aquat. Conserv. Mar. Freshw. Ecosyst. 27:2656. doi: 10.1002 aqc. 2656

Coleman, A. T., Pulis, E. E., Pitchford, J. L., Crocker, K., Heaton, A., Carron, A. M., et al. (2016b). Population ecology and rehabilitation of incidentally captured Kemp's ridley sea turtles (Lepidochelys kempii) in the Mississippi Sound. Herpetol. Conserv. Biol. 11, 253-264.

Connelly, N. A., Siemer, W. F., Decker, D. J., and Allred, S. B. (2012). "Methods of human dimensions inquiry," in Human Dimensions Of Wildlife Management, 2nd Edn, eds D. J. Decker, S. J. Riley, and W. F. Siemer (Baltimore MD: The Johns Hopkins University Press), 122-138.

Draugalis, J. R., Coons, S. J., and Plaza, C. M. (2008). Best practices for survey research reports: a synopsis for authors and reviewers. Am. J. Pharm. Edu. 72:11. doi: 10.5688/aj720111

Fowler, F. J. (2014). Survey Research Methods, 5th Edn, London: Sage Publication.

Gallaway, B. J., Gazey, W. J., Caillouet, C. W. Jr., Plotkin, P. T., Abreu Grobois, F., et al. (2016). Development of a Kemp's ridley sea turtle stock assessment model. Gulf Mex. Sci. 33, 138-157.

Heaton, A. J., Pulis, E. E., Pitchford, J. L., Hatchett, W. L., Carron, A. M., and Solangi, M. (2016). Prevalence and transience of ingested fishing hooks in Kemp's ridley sea turtles. Chelonian Conserv. Biol. 15, 257-264. doi: 10.2744/ CCB-1227.1

\section{ACKNOWLEDGMENTS}

The authors thank all of the interviewers, especially Brittany Carmon and Victoria Howard, and Jamie Shelly for developing the database. Thanks to all of the stranding responders in the Mississippi Sea Turtle Stranding and Salvage Network. We would also like to show gratitude to the NOAA College-Supported Internship Program funded by the Agnes Shedd Andreae 1932 Research Internship Fund, for providing funding which allowed VD to intern with Mississippi Laboratories. Finally, we would like to thank the fishing community of the Mississippi Gulf Coast for partaking in this study and the independent reviewers whose comments and suggestions improved this manuscript.

\section{SUPPLEMENTARY MATERIAL}

The Supplementary Material for this article can be found online at: https://www.frontiersin.org/articles/10.3389/fmars. 2020.00655/full\#supplementary-material

Hendra, R., and Hill, A. (2019). Rethinking response rates: new evidence of little relationship between survey response rates and nonresponse bias. Eval. Rev. 43, 307-330. doi: 10.1177/0193841X18807719

Henwood, T. A., and Stuntz, W. E. (1987). Analysis of sea turtles captures and mortalities during commercial shrimp trawling. Fish. Bull. 85, 813-817.

Lyn, H., Coleman, A., Broadway, M., Klaus, J., Finerty, S., Shannon, D., et al. (2012). Displacement and site fidelity of rehabilitated immature Kemp's ridley sea turtles (Lepidochelys kempii). Mar. Turtle Newsl. 135, $10-13$.

Marquez, M. R. (1994). Synopsis of Biological Data On The Kemp's Ridley Turtle Lepidochelys kempii (Garman 1880). U.S. Dept. of Commerce, NOAA Tech. Memo. NMFS-SEFSC-343, 91. Silver Spring, MD: NOAA.

National Marine Fisheries Service (2016). Fisheries Economics Of The United States, 2014. U.S. Dept. of Commerce, NOAA Tech. Memo. NMFS-F/SPO-163, 237. Silver Spring, MD: National Marine Fisheries Service.

National Marine Fisheries Service (2017). Fisheries Economics Of The United States, 2015. U.S. Dept. of Commerce, NOAA Tech. Memo. NMFS-F/SPO-170, 247. Silver Spring, MD: National Marine Fisheries Service.

National Marine Fisheries Service, U. S. Fish and Wildlife Service, and SEMARNAT (2011). Bi-National Recovery Plan For The Kemp's Ridley Sea Turtle (Lepidochelys kempii), 2nd Revision. Silver Spring, MD: National Marine Fisheries Service.

Nederhof, A. J. (1985). Methods of coping with social desirability bias: a review. Eur. J. Soc. Psychol. 15, 263-280. doi: 10.1002/ejsp.2420150303

Poiner, I. R., and Harris, A. N. M. (1996). Incidental capture, direct mortality and delayed mortality of sea turtles in Australia's northern prawn fishery. Mar. Biol. 125, 813-825. doi: 10.1007/bf00349264

Ramirez, M. D., Avens, L., Goshe, L. R., Snover, M. L., Cook, M., and Heppell, S. S. (2020). Regional variation in Kemp's ridley sea turtle diet composition and its potential relationship with somatic growth. Front. Mar. Sci. 7:253. doi: 10.3389/fmars.2020.00253

Robson, D., and Jones, C. M. (1989). The theoretical basis of an access site angler survey design. Biometrics 45, 83-98.

Rose, S. A., O’Hara, K. J., and Barco, S. G. (2018). Sea Turtles And Fishing Piers In Virginia: Mitigating Hook And Line Interactions. Virginia: Virginia Aquarium and Marine Science Center.

Rudloe, A., and Rudloe, J. (2005). Site specificity and the impact of recreational fishing activity on subadult endangered Kemp's ridley sea turtles in estuarine foraging habitats in the northeastern Gulf of Mexico. Gulf Mex. Sci. 23, 186-191. doi: $10.18785 /$ goms.2302.05 
Sasso, C. R., and Epperly, S. P. (2006). Seasonal sea turtle mortality risk from forced submergence in bottom trawls. Fish. Res. 81, 86-88. doi: 10.1016/j.fishres.2006. 05.016

Seney, E. E., and Musick, J. A. (2005). Diet analysis of Kemp's ridley sea turtles (Lepidochelys kempii) in Virginia. Chelonian Conserv. Biol. 4, 864-871.

Shaver, D. J., Hart, K. M., Fujisaki, I., Rubio, C., Sartain, A. R., et al. (2013). Foraging area fidelity for Kemp's ridleys in the Gulf of Mexico. Ecol. Evol. 3, 2002-2012. doi: 10.1002/ece3.594

Shaver, D. J., Hart, K. M., Fujisaki, I., Rubio, C., Sartain-Iverson, A. R., et al. (2016). Migratory corridors of adult female Kemp's ridley turtles in the Gulf of Mexico. Biol. Conserv. 194, 158-167. doi: 10.1016/j.biocon.2015.12.014

Stacy, B. A. (2015). Summary of Necropsy Findings for Non-Visibly Oiled Sea Turtles Documented by Stranding Response in Alabama, Louisiana, and Mississippi 2010 through 2014. DWH Sea Turtles NRDA Technical
Working Group Report. Silver Spring, MD: U.S. Department of Commerce.

Wibbels, T., and Bevan, E. (2019). Lepidochelys kempii (errata version published in 2019). IUCN Red List Threat. Spec. 2019:e.T11533A155057916.

Conflict of Interest: The authors declare that the research was conducted in the absence of any commercial or financial relationships that could be construed as a potential conflict of interest.

Copyright (c) 2020 Cook, Dunch and Coleman. This is an open-access article distributed under the terms of the Creative Commons Attribution License (CC BY).

The use, distribution or reproduction in other forums is permitted, provided the original author(s) and the copyright owner(s) are credited and that the original publication in this journal is cited, in accordance with accepted academic practice. No use, distribution or reproduction is permitted which does not comply with these terms. 